International Journal of Language Education and Culture Review, Vol.2 (2) December 2016, 9 - 13.

Available online at http://journal.unj.ac.id/unj/index.php/ijlecr

DOI:doi.org/10.21009/IJLECR.022.02

\title{
THE EFFECT OF LEARNING MODEL AND CREATIVE THINKING ABILITY ON STUDENTS' RECOUNT WRITING SKILL
}

\author{
Aria Septi Anggaira ${ }^{1}$ Zainal Rafli $^{2}$ \\ Junior High School Four Metro Lampung, Indonesia ${ }^{1}$ \\ Universitas Negeri Jakarta, Indonesia ${ }^{2}$ \\ ariasepti@yahoo.com ${ }^{1}$ \\ zainal.rafli@gmail.com²
}

\begin{abstract}
The aim of the study is to find out the effect of learning model and creative thinking ability on students' recount writing skill. It was an experimental study with $2 \times 2$ factorial design and analysed using two-factor ANOVA at 0.05 significance level. The sample was 32 students and divided into two groups, namely experiment and control. The data were collected using recount writing test in English and creative thinking ability test. The research finding showed: (1) the students' recount writing skill taught by project-based learning model was higher than by genre-based learning model, (2) there was interaction between learning model and creative thinking ability on students ' recount writing skill, (3) the students' recount writing skill with high creative thinking ability taught by project-based learning model was higher than those by genre-based learning model, and (4) the students' recount writing skill with low creative thinking ability taught by project-based learning model was lower than those by genre-based learning model.
\end{abstract}

Keywords: project-based, genre-based, writing, recount, creative thinking ability.

Writing is one of the four language skills (listening, speaking, reading, and writing). In learning process all of the skills should get a portion of a balanced, integrated and thematically. But in fact the students assume that writing skills is perceived as the most difficult skills than other skills. Richards and Renandya stated that, "There is no doubt that writing is the most difficult skill for L2 learners to master. The difficulty lays not only generating and organizing ideas, but also in translating these ideas into readable text" (2002:303). This is because in the writing class, students are expected not only to develop their ability to make a bouquet, but also the ability to pour or ideas by creating a bouquet of interesting reading. Writer explores and discovers ideas as they write (Hyland, 2009: 80). There are plenty of activities in the writing process. All these activities require a greater ability of the person who will write. As Moore-Hart states that writing is communicating, thinking, imagining, remembering, collecting information, accessing information, or storing ideas in memory (2010: 1). This is what makes learning writing in junior high school quite heavy for the students. 
Teachers also experienced the same thing when teaching writing skill. Teacher was not effective in teaching writing because lack of interest in learning writing. As Teo states, since writing is a complex problem-solving process, teachers are recommended to intervene at points in the writing process that can most benefit the writers (2006). So obviously in the process of learning to write the teacher has an important role, one of this is as supervisor for the students in the writing process.

One type of writing that learned in junior high school students is writing recount (Kemendikbud: 2014). This means, grade 8 students are already required to be able to make recount text, corresponding to the structure of language that is characteristic of recount text, among them are the ideas that exist in the form of writing, using a form of time corresponding to the characteristics of the text recount, the past tense, using a marker to the appropriate time, using the pronoun of right person, then compose the text recount be unified so that more meaningful, and the important thing is exploring their ability to think creatively when writing (Derewianka, 2004: 15-17). In fact, students face many problems in writing a recount text.

In teaching writing most of the teachers do not use approach, teaching model, teaching methods, learning strategies, or specific learning techniques for teaching writing. This phenomenon happens in most junior high schools in Metro city, especially in SMP 4 Metro. In this study, researcher chose two learning models of teaching. Dewey says, a model of teaching is a description of a learning environment, including our behavior as teachers when that model is used. These models have many uses, ranging from planning lessons and curriculums to designing instructional materials, including multimedia programs (Joyce, 2009: 24). The two models used in this study are a project-based learning model and genre-based learning model.

Both models have been learning in order to solve the difficulties of learning recount text experienced by students in class VIII SMP Negeri 4 Metro-Lampung. Phyllis C. Blumenfeld et al say that Project-Based Learning is a comprehensive approach to classroom teaching and learning that is designed to engage students in investigation of authentic problems (1991: 369). Project-based learning is applied to motivate students to be more active and take the initiative to get the things they want on the knowledge, understanding and skills. While a genre-based approach is writing instruction looks beyond subject content, composing processes and linguistic forms to see a text as attempts to communicate with readers (Emilia, 2010 :160-162). A genrebased approach deals with learning integrating linguistic competence and communication competence to build competence in discourse within language learners. So it can be believed both learning model can be applied to both in teaching of writing.

Teaching recount text in particular, need an addition to appropriate learning models, the ability to think can influence the students' writing skills. For recount writing, the ability which is needed is to think creatively. Creative thinking is a wide variety of mental activity that occurs in the person's thinking process. Johnson says that creative thinking involves seeking opportunities to change things for the better (2002, 117).

Creative thinking involves a variety of different thoughts on everyone. That is, creative thinking is a process that happens to everyone, it's just that the level of ability 
is different. Different creative thinking abilities were divided into high creative thinking skills and low creative thinking ability. With the difference in the level of creative thinking ability is believed will influence the writing produced by students. Therefore, teachers also have a role in developing the creative thinking abilities of students in writing, especially in writing recount text.

\section{METHOD}

The method used in this research is the experimental method, the design of treatment by the level of $2 \times 2$. The study involved two independent variables with two levels of learning model that includes project-based learning model and the genrebased learning model and creative thinking abilities that consists of high creative thinking ability and low creative thinking ability and the dependent variable is the ability to write a recount.

\section{RESULT AND DISCUSSION Results SPSS Analysis of Variance Tests of Between-Subjects Effects}

Dependent Variable: Recount Writing Skill

\begin{tabular}{|l|r|r|r|r|r|}
\hline Source & $\begin{array}{c}\text { Type III Sum } \\
\text { of Squares }\end{array}$ & Df & Mean Square & \multicolumn{1}{c|}{ F } & \multicolumn{1}{c|}{ Sig. } \\
\hline Corrected Model & $799.344^{\mathrm{a}}$ & 3 & 266.448 & 28.847 & .000 \\
Intercept & 168345.031 & 1 & 168345.031 & $1.823 \mathrm{E} 4$ & .000 \\
ModelPembelajaran & 81.281 & 1 & 81.281 & 8.800 & .006 \\
KemampuanBerpikirKr & 42.781 & 1 & 42.781 & 4.632 & .040 \\
eatif & & & & & \\
ModelPembelajaran * & 675.281 & 1 & 675.281 & 73.109 & .000 \\
KemampuanBerpikirKr & & & & & \\
eatif & 258.625 & 28 & 9.237 & & \\
Error & 169403.000 & 32 & & & \\
Total & 1057.969 & 31 & & & \\
Corrected Total & & & & \\
\hline
\end{tabular}

a. $\mathrm{R}$ Squared $=.756$ (Adjusted R Squared $=.729$ ) explained:

Based on the analysis of two paths variance (ANOVA) above, it can be

Based on the results of two-way analysis of variance on line $\mathrm{A}$ is found that $\mathrm{F}$ counts larger than $F$ table $(F$ count $=8.80>F$ table $(0.05 ; 1: 28)=4.20)$. This shows that the recount writing skills scores of students there are significant differences between project-based learning model and genre-based learning model. This difference is shown by the average value score recount writing skills of students who receive treatment with project-based learning model at 74.13 and the average score of students recount writing skills that are subjected to the genre -based learning model at 70.94 . 
This means that there is a difference scores recount writing skills of students who receive treatment with project-based learning model and scores recount writing skills of students who receive treatment with genre-based learning model.

The results of two-way analysis of variance on line $\mathrm{A} * \mathrm{~B}$ is found that $\mathrm{F}$ counts interaction $\mathrm{AB}$ is greater than $\mathrm{F}$ table $(\mathrm{F}$ count $=73.08>\mathrm{F}$ table $(0.05 ; 1: 28)=4.20)$. its means that there is a very significant interaction effect between learning models and creative thinking ability to recount writing skills. Because there is a very significant interaction effect, then followed by Tukey's test cell fourth experimental design.

The results of Tukey Test on students who have creative thinking ability, the value $\mathrm{Q}$ count $=11.57$ is greater than $\mathrm{Q}$ table $(0.05 ; 4: 8)=4.53$. its means that there is a difference score writing skills recount of students who receive treatment with projectbased learning model and were treated with a genre-based learning model for a group of students who have high creative thinking ability. It can be concluded that the score writing skills recount of students who have high creative thinking ability, in the group treated with the project-based learning model is higher than the group treated with the genre-based learning model.

Results of Tukey test showed students who have low creative thinking ability values obtained $Q$ count $=5.61$ is greater than $Q$ table $(0.05 ; 4: 8)=4.53$. its means that there is a difference score writing skills recount of students who receive treatment with the project-based learning model and were treated with genre-based learning model for a group of students who have low creative thinking ability. It can be concluded that the score of recount writing skills for students who have low creative thinking ability in the group treated with the genre-based learning model is higher than the group treated with the project-based learning.

\section{CONCLUSION}

(1) Recount writing skill in the group of students who receive treatment with projectbased learning model is higher than the group of students that used the genre-based learning model. (2) There is an interaction effect between learning models and the ability to think creatively to recount writing skill. (3) Recount Writing skills of students who receive treatment with the project-based learning model and possess high creative thinking ability is higher than the recount writing skill of students who receive treatment with genre-based learning model on students with high creative thinking ability. (4) Recount writing skill of students who receive treatment with the projectbased learning model with low creative thinking ability is lower than the recount writing skill of students who receive treatment with genre-based learning model on students have low creative thinking ability. 


\section{REFERENCES}

Derewianka, Beverly. 2004. Exploring How Text Work. Victoria: Pherson'mP rinting Group.

Hyland, Ken. 2009. Teaching and Researching Writing: 2nd Edition. Great Britain: Pearson Education Limited.

Richards. C.Jack. dan Willy A. Renandya. 2002. .Methodology in Language Teaching: An Anthology of Current Practice. United States of America: Cambridge University Press.

Emilia, Emi. 2010. Teaching Writing: Developing Critical Learners. Ledeng Bandung; Rizqi Press.

Johnson. Elaine B. 2002. Contextual Teaching and Learning: what it is why it s here to say. California: Corwin Press.

Joyce, B. and Weil, Model of Teaching. Boston: Pearson Education, 2009.

Kementerian Pendidikan dan KebudayaanModul. 2014. Pelatihan Implementasi Kurikulum 2013. Jakarta : Badan Pengembangan Sumberdaya Manusia Pendidikan dan Kebudayaan dan Penjaminan Mutu Pendidikan Kementerian Pendidikan dan Kebudayaan.

Moore-Hart. Margaret A. 2010. Teaching Writing in Diverse Classroom, K-8 United States of America: Pearson Education Ltd.

Blumenfeld. Phyllis C. et al., 1991. "Motivating Project-based Learning: Sustaining the Doing, Supporting the Learning", Journal of educational Psychologist, Vol.26(3\&4).

Teo, Adeline (Lei) K. 2006. "Using a Peer Assisted Writing Activity to Promote ESL/EFL Students' Narrative Writing Skills", The Internet TESL Journal, Vol. XII, No. 8, August. 